\title{
Early treatment with captopril after acute myocardial infarction
}

Simon G Ray, Maurice Pye, Keith G Oldroyd, James Christie, Derek T Connelly, David B Northridge, Ian Ford, James J Morton, Henry J Dargie, Stuart M Cobbe

\begin{abstract}
Objectives-To determine the effects of early treatment with captopril on haemodynamic function, neuroendocrine biochemistry, left ventricular structure, clinical outcome, and exercise capacity over one year from acute myocardial infarction.
\end{abstract}

Design-Randomised, double blind, placebo controlled comparison of captopril and placebo.

Setting-Coronary care units and cardiology departments of two university teaching hospitals in Glasgow.

Patients-99 haemodynamically stable patients with acute myocardial infarction, selected on clinical grounds as being at risk of late ventricular dilatation.

Intervention-Captopril or identical placebo started between six and 24 hours after start of symptoms and continued for 12 months. Target maintenance dose was $25 \mathrm{mg}$ three times a day.

Main outcome measures-(a) Acute haemodynamic effects of treatment; (b) neuroendocrine biochemistry from admission to two months; and (c) change in echocardiographic measures of left ventricular size, clinical outcome, and exercise capacity after 12 months of treatment with a separate analysis of the effects of one month of treatment withdrawal on left ventricular volumes.

Results-Captopril caused acute reductions in mean (SEM) pulmonary artery pressure $(2.48(0.69) \mathrm{mm} \mathrm{Hg})$ and systemic vascular resistance $(260$ (103)) dyn. s. $\mathrm{cm}^{-5}$ ). Over the first 10 hours captopril reduced mean arterial pressure by $12 \cdot 1(2 \cdot 4) \mathrm{mm} \mathrm{Hg}$ compared with $3.8(1.9)$ $\mathrm{mm} \mathbf{~ H g}$ in the placebo group. No patient had to be withdrawn from the captopril group because of hypotension. From day 1 onwards systolic and diastolic arterial pressures in the captopril treated group were slightly but not significantly lower than on placebo. There was no difference in the incidence of ventricular or supraventricular arrhythmia with treatment. Captopril prevented the day 3 peak in angiotensin II that occurred in the placebo group (peak concentration (interquartile range): $10 \cdot 1(4 \cdot 8-19 \cdot 4) \mathrm{pg} / \mathrm{ml}$ $v 16 \cdot 8(4 \cdot 3-46 \cdot 3) \mathrm{pg} / \mathrm{ml})$ ) but had no effect on atrial natriuretic factor, arginine vasopressin, or catecholamines. Plasma atrial natriuretic factor remained above normal in both groups at two months after infarction. After one year left ventricular volume indices had increased less on captopril than on placebo: left ventricular end systolic volume index 5.4 $\mathrm{ml} / \mathrm{m}^{2}$ v $14.7 \mathrm{ml} / \mathrm{m}^{2} \quad(95 \%$ confidence interval $(95 \% \mathrm{CI})$ of difference -14.6 to -3.9; $p=0.0011)$; left ventricular end diastolic volume index $8.4 \mathrm{ml} / \mathrm{m}^{2} v 19.0$ $\mathrm{ml} / \mathrm{m}^{2}(95 \%$ CI of difference, $-17 \cdot 0$ to $-4 \cdot 2 ; p=0 \cdot 0016)$. Withdrawal of captopril for one month did not affect ventricular volumes. There was no difference in exercise capacity.

Conclusions-Captopril started between six and 24 hours after acute myocardial infarction is not associated with significant hypotension. It suppresses activation of the renin angiotensin system but has no effect on plasma concentrations of other neurohormones. Atrial natriuretic factor remains raised at two months after myocardial infarction. Captopril significantly decreases left ventricular dilatation. This effect is not lost after one month of treatment withdrawal and is thus due to an alteration of left ventricular structure and not to a short lived haemodynamic action of captopril. Long-term treatment with captopril does not result in improved aerobic exercise capacity after acute myocardial infarction.

(Br Heart f 1993; 69:215-222)

Significant left ventricular dilatation occurs in $20 \%-25 \%$ of patients with acute transmural myocardial infarction. ${ }^{12}$ Ventricular enlargement is associated with the development of cardiac failure and an adverse prognosis. ${ }^{34}$ Treatment strategies that limit progressive ventricular remodelling have the potential to lessen the incidence of late cardiac failure and death. Captopril started a week or more after the infarction limits left ventricular enlargement. ${ }^{56}$ Experimental and clinical evidence suggests that the process of left ventricular dilatation begins early after transmural myocardial necrosis and develops rapidly in the first few days at a time when the renin angiotensin system is activated. ${ }^{5-9}$ Prompt intervention with captopril may attenuate this early rapid phase of left ventricular dilatation and maximise its beneficial effects on left ventricular function. The aim of this study was to examine the acute haemodynamic effects of captopril started within 24 hours of acute myocardial infarction and to determine its 
long-term actions on neuroendocrine biochemistry, left ventricular structure, clinical outcome, and exercise capacity. A preliminary analysis of the early effects of captopril on left ventricular remodelling in these patients has been the subject of a separate report. ${ }^{10}$

\section{Patients and methods}

This was a two centre double blind placebo controlled comparison of captopril and placebo started within 24 hours of acute myocardial infarction. The study protocol was approved by the ethics committees of both institutions and all patients gave informed consent. We recruited 99 clinically and haemodynamically stable patients ( 82 men 17 women) aged 40-75 years and admitted within 24 hours of the start of chest pain. Electrocardiographic requirements for entry were ST elevation of at least $3 \mathrm{~mm}$ in 2 precordial leads V1-V4 or $2 \mathrm{~mm}$ in two frontal plane leads or V5-6 or any ST elevation in two frontal plane leads with ST depression compatible with posterior wall infarction of at least $3 \mathrm{~mm}$ in two precordial leads. To avoid recruiting patients with small infarcts and at low risk of ventricular dilatation we excluded those with a Norris score $<3 \cdot 5 .{ }^{11}$ Other exclusion criteria were systolic blood pressure $<95$ $\mathrm{mm} \mathrm{Hg}$ on admission, history of significant renal or cerebrovascular disease, contraindications to captopril, or a definite indication for its use and inability to give informed consent. At the time of recruitment into this study, the policy in our coronary care units was not to give thrombolytic treatment to patients seen six or more hours after the start of symptoms. These patients, plus those in whom contraindications to thrombolytic treatment existed, were eligible for recruitment into our study. After randomisation and baseline investigations patients received $6.25 \mathrm{mg}$ of the trial medication, which if tolerated was repeated at one hour. At eight hours $12.5 \mathrm{mg}$ was given then $12.5 \mathrm{mg}$ three times daily with a target dose of $25 \mathrm{mg}$ three times daily before discharge from hospital. If the systolic blood pressure was persistently less than $85 \mathrm{~mm} \mathrm{Hg}$ the next scheduled dose was omitted and the subsequent dose halved. If despite dose reduction systolic blood pressure remained persistently less than $85 \mathrm{~mm} \mathrm{Hg}$ the patient was withdrawn from the study. Other withdrawal criteria were serum urea $>20 \mathrm{mmol} / 1$ despite dose reduction, development of cardiac failure requiring open label captopril or any condition defined previously as an exclusion criterion, or a severe adverse drug effect thought to be related to captopril. All medications except angiotensin converting enzyme inhibitors could be given at the discretion of the individual physician. Table 1 shows the baseline characteristics of the treatment groups.

\section{CLINICAL FOLLOW UP}

Patients underwent a detailed clinical assessment on admission and on days $1,2,3$, and 7 to 10 and at one, two, four, six, nine, and 12 months when trial medication was withdrawn. A further assessment was made at 13 months, one month after withdrawal from treatment. In one centre 41 patients had $7 F$ thermodilution Swan Ganz catheters inserted through the internal jugular or brachiocephalic veins to record cardiac filling pressures and cardiac output before and after the first two doses of captopril. All measurements were made in triplicate in end expiration. For the first 72 hours after admission heart rate and rhythm were monitored continuously on a central console. Holter recorders were attached for 24 hours after admission and immediately before discharge from hospital for detailed analysis of arrhythmias. Continuous wave Doppler echocardiography was performed at baseline, at day 3, and at days 7-10. The cardiac index was derived from standard formulae. ${ }^{12}$

\section{NEUROENDOCRINE DATA}

Before the first dose of trial medication an indwelling forearm cannula was inserted and after 30 minutes supine rest venous blood was drawn for assay of atrial natriuretic factor, renin, angiotensin II, arginine vasopressin, adrenaline, and noradrenaline. Sampling was repeated by the same technique at day 3 , days seven to 10 , and at two months. At all time points from admission sampling was performed about two hours after the last dose of trial medication. All assays were performed in the laboratories of the Medical Research Council Blood Pressure Unit with previously described techniques. ${ }^{13-17}$ Normal ranges are: atrial natriuretic factor $5-50 \mathrm{pg} / \mathrm{ml}$; renin $9-50 \mu \mathrm{u} / \mathrm{ml}$; angiotensin II $<20 \mathrm{pg} / \mathrm{ml}$, arginine vasopressin $0.3-0.7 \mathrm{pg} / \mathrm{ml}$; adrenaline $<1 \mathrm{nmol} / \mathrm{l}$; noradrenaline $<5 \mathrm{nmol} / 1$.

\section{ECHOCARDIOGRAPHY}

Cross sectional echocardiography was performed on days 1,3 , and 7 to 10 and at one, two, six, 12, and 13 months. Three experienced echocardiographers obtained all the ultrasound data. A short axis parasternal view of the left ventricle at the level of the tips of the papillary muscles in end diastole was used to measure anterior and posterior endocardial segment lengths as previously described. ${ }^{18}$ Left ventricular volumes were calculated in one centre by the method of Tortoledo et al ${ }^{19}$ and in the other by a 10 segment Simpson's rule method. ${ }^{20}$ Patient and transducer positions were recorded at the initial scan and maintained between successive examinations. All measurements were averaged over three consecutive cardiac cycles. All images for an individual patient were acquired and analysed by the same operator. Day to day intraobserver variability was determined from a random sample of 30 patients (10 for each operator) examined twice within a 48 hour period at the end of the study. ${ }^{21}$ Each of these scans was recorded on a separate video tape, coded, and analysed blind at the end of the study. The SDs of repeated measurements were: left 
ventricular end diastolic volume index $6.1 \mathrm{ml} / \mathrm{m}^{2}$, left ventricular end systolic volume index $6.2 \mathrm{ml} / \mathrm{m}^{2}$, anterior segment length $5 \mathrm{~mm}$, posterior segment length $5 \mathrm{~mm}$. A change within any individual patient that was greater than two SDs of the measurement error was considered significant.

\section{EXERCISE TESTS}

Before discharge treadmill exercise testing was undertaken on a modified Bruce protocol limited to nine minutes. Symptom limited cardiopulmonary exercise testing on a Bruce protocol was performed at 12 and 13 months. Respiratory variables were measured on a Beckman metabolic measurement chart (Horizon).

\section{STATISTICAL ANALYSIS}

The study was analysed on a limited intention to treat basis with all available patients at each time point. A separate analysis was performed comparing one year and 13 months to determine the effects of withdrawal from treatment. Categorical variables were analysed with the $\chi^{2}$ or Fisher's exact tests and continuous variables with unpaired Student's $t$ test incorporating the AspinWelch modification or the Mann-Whitney U test. The Bonferroni correction was used as appropriate to allow for multiple comparisons. ${ }^{22}$ Data are expressed as mean (SEM) except for the neuroendocrine data, which are expressed as median and interquartile range.

\section{Results}

CLINICAL OUTCOMES

At baseline the two treatment groups were well matched except for an inequality in the distribution of patients with a previous myocardial infarction (table 1). Over one year of follow up there were eight deaths (four sudden) in the captopril group and 10 (six sudden) in the placebo group. Thirteen of these patients died within two months of infarction. All five deaths between two months and one year were in the placebo group. Table 2 shows only twenty two patients were withdrawn from the study medication. Seventy three patients were available for analysis at the end of the study including 14 patients who had been withdrawn from the study medication but who had continued blinded follow up. There was no difference in the use of non-trial cardiac drugs at one year.

\section{HAEMODYNAMIC FUNCTION}

At baseline cardiac filling pressures tended to be higher and cardiac output lower in the captopril group (table 1). Over the 10 hour period from initial dosing captopril caused a significantly greater fall in mean arterial pressure than did placebo (fig 1). The fall in blood pressure in the captopril group was not associated with a rise in heart rate (fig 2). There was no relation between the fall in mean arterial pressure and the admission concentration of angiotensin II. At two hours there had been small but significant falls in
Table 1 Baseline characteristics

\begin{tabular}{|c|c|c|}
\hline & $\begin{array}{l}\text { Captopril } \\
(n=49)\end{array}$ & $\begin{array}{l}\text { Placebo } \\
(n=50)\end{array}$ \\
\hline Age (yr) & $61(1)$ & $59(1)$ \\
\hline $\operatorname{Sex}(M / F)$ & $40 / 9$ & $42 / 8$ \\
\hline Previous AMI & 2 & $13^{\star}$ \\
\hline Peak CK (IU) & $288 \overline{7}(318)$ & $2334(242)$ \\
\hline Killip class 1 & 32 & 31 \\
\hline 2 & 14 & 19 \\
\hline 3 & 3 & 0 \\
\hline Norris index & $6 \cdot 2(0.2)$ & $6 \cdot 3(0 \cdot 2)$ \\
\hline \multicolumn{3}{|l|}{ Infarct site: } \\
\hline Anterior & 28 & 31 \\
\hline Inferoposterior & 21 & 19 \\
\hline Time to start of treatment $(\mathrm{h})$ & $14 \cdot 3(1 \cdot 0)$ & $16.6(0.9)$ \\
\hline Heart rate & $78(3)$ & $83(2)$ \\
\hline Systolic BP & $133(3)$ & $131(4)$ \\
\hline Diastolic BP & $86(2)$ & $83(2)$ \\
\hline RAP & $8.4(0.9)$ & $7 \cdot 3(0 \cdot 6)$ \\
\hline PAMP & $25 \cdot 2(1 \cdot 6)$ & $22 \cdot 0(1 \cdot 3)$ \\
\hline PAWP & $15 \cdot 8(1 \cdot 5)$ & $13.9(1.3)$ \\
\hline $\mathrm{CO}(1 / \mathrm{min})$ & $4 \cdot 26(0 \cdot 32)$ & $4.6(0.24)$ \\
\hline SVR (dyn.s.cm $\left.{ }^{-5}\right)$ & $1891(136)$ & $1610(127)$ \\
\hline LVESVI $\left(\mathrm{ml} / \mathrm{m}^{2}\right)$ & $42 \cdot 7(2 \cdot 2)$ & $47 \cdot 3(2 \cdot 2)$ \\
\hline $\operatorname{LVEDVI}\left(\mathrm{m} / \mathrm{m}^{2}\right)$ & $67.7(2.5)$ & $72 \cdot 5(2 \cdot 1)$ \\
\hline $\mathrm{SVI}\left(\mathrm{ml} / \mathrm{m}^{2}\right)$ & $25.0(1.4)$ & $25 \cdot 2(1 \cdot 3)$ \\
\hline EF\% & $37 \cdot 4(1 \cdot 8)$ & $35 \cdot 2(1 \cdot 8)$ \\
\hline
\end{tabular}

${ }^{\star} p=0.002$. AMI, acute myocardial infarction; CK, creatine kinase; BP, blood pressure: RAP, right atrial pressure; PAMP, mean pulmonary artery pressure; PAWP, pulmonary artery wedge pressure; CO, cardiac output; SVR, systemic vascular redistance (invasive haemodynamics are for 41 patients only); resistance (invasive haemodynamics are for 41 patients only); LVESVI, left ventricular end diastolic volume index; SVI,
stroke volume index; EF, ejection fraction. Values are mean (SEM) where applicable.
(SEM) volume index; EF,

Table 2 Reasons for withdrawal

\begin{tabular}{lll}
\hline & Captopril & Placebo \\
\hline Cardiac failure & 2 & 2 \\
Reinfarction & 3 & 1 \\
Unstable angina & 0 & 3 \\
CABG & 1 & 1 \\
LV aneurysmectomy & 1 & 0 \\
Hypotension & 0 & 1 \\
Cough & 1 & 0 \\
Non-compliance & 2 & 1 \\
Other illness & 2 & 1 \\
\hline
\end{tabular}

LV, left ventricular; CABG, coronary artery bypass grafting

mean pulmonary artery pressure and systemic vascular resistance in the captopril group compared with small rises in the placebo group (table 3), but no increase in cardiac output. From day 1 both systolic and diastolic blood pressure in the captopril group remained slightly but not significantly lower than in the placebo group (table 4). There was no significant difference in cardiac index by Doppler ultrasound between the treatment groups (fig 3).

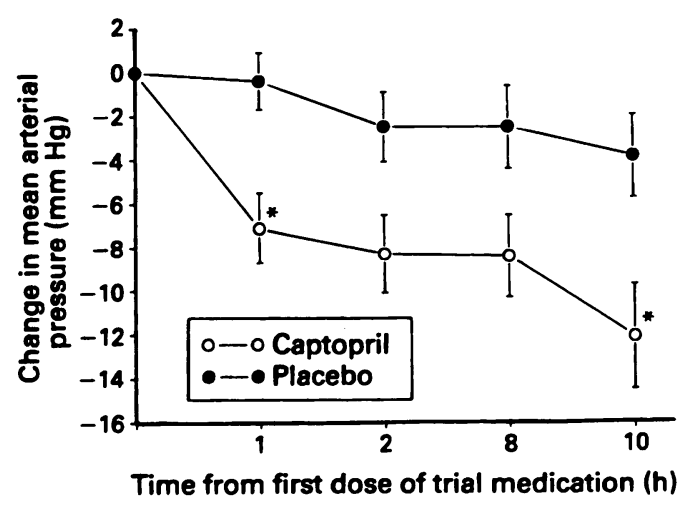

Figure 1 Change in mean (SEM) arterial pressure from baseline. ${ }^{*} p<0.05$. 
Figure 2 Change in mean (SEM) heart rate from baseline.

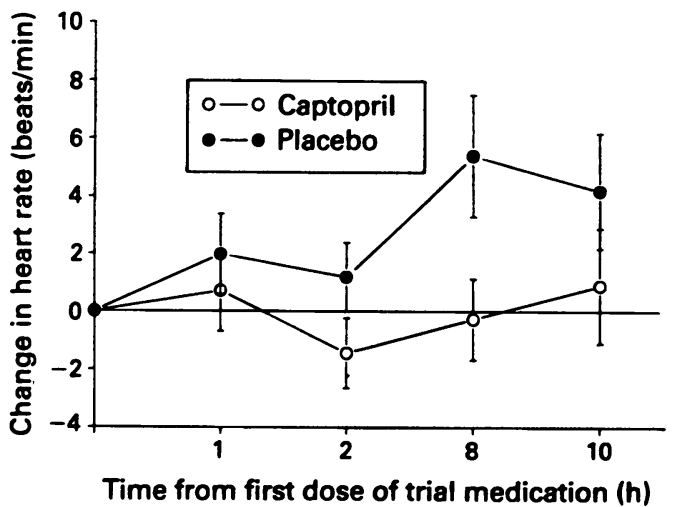

\section{ARRHYTHMIAS}

There was no difference in the incidence of ventricular or supraventricular arrhythmias between the treatment groups either after admission or before discharge.

\section{NEUROENDOCRINE RESPONSES}

Pretreatment concentrations of all hormones except adrenaline tended to be higher in the captopril group (table 5). In the placebo group concentrations of renin and angiotensin II rose from admission to day 3. This trend was present even in those patients not treated with diuretics. In this subgroup median plasma renin concentrations rose from $27 \mu \mathrm{u} / \mathrm{ml}$ on admission to $64 \mu \mathrm{u} / \mathrm{ml}$ at day 3, and fell to $39 \mu \mathrm{u} / \mathrm{ml}$ at days $7-10$. Corresponding angiotensin II concentrations were $11.0 \mathrm{pg} / \mathrm{ml}, 13.6 \mathrm{pg} / \mathrm{ml}$, and $8.7 \mathrm{pg} / \mathrm{ml}$. Captopril caused a considerable increase in renin concentration and suppressed the rise in angiotensin II seen in the placebo group. Plasma atrial natriuretic factor peaked at three days in both treatment groups, and remained above normal throughout the study

Table 3 Change in invasive haemodynamics from baseline to two hours

\begin{tabular}{|c|c|c|}
\hline & $\begin{array}{l}\text { Captopril } \\
(n=21) \\
\text { Mean (SEM) }\end{array}$ & $\begin{array}{l}\text { Placebo } \\
(n=20) \\
\text { Mean }(S E M)\end{array}$ \\
\hline $\begin{array}{l}\text { RAP } \mathrm{mm} \mathrm{Hg} \\
\text { PAMP } \mathrm{mm} \mathrm{Hg} \\
\text { PAWP } \mathrm{mm} \mathrm{Hg} \\
\text { CO } 1 / \mathrm{min} \\
\text { SVR dyn.s.cm } \\
\end{array}$ & $\begin{array}{l}-\quad 0.92(0.82) \\
-\quad 2.48(0.69)^{\star \star} \\
-\quad 1.91(1.0) \\
-\quad 0.06(0.08) \\
-\quad 260(103)^{\star}\end{array}$ & $\begin{array}{l}1.55(1.7) \\
0.75(0.77) \\
1.18(1.5) \\
-0.13(0.17) \\
72(54)\end{array}$ \\
\hline
\end{tabular}

${ }^{\star} \mathrm{p}<005,{ }^{\star \star} \mathrm{p}<0.01$

RAP, right atrial pressure; PAMP, mean pulmonary arterial pressure; PAWP, pulmonary artery wedge pressure; $\mathrm{CO}$, cardiac output, SVR, systemic vascular resistance.

Table 4 Serial heart rates and blood pressures from baseline to 13 months

\begin{tabular}{|c|c|c|c|c|c|c|}
\hline & Baseline & Day 1 & Day 3 & Days $7-10$ & Two months & One yr \\
\hline $\begin{array}{l}\text { HR } \\
\text { SBP } \\
\text { DBP }\end{array}$ & $\begin{array}{r}78(3) \\
133(3) \\
86(2)\end{array}$ & $\begin{array}{r}80(3) \\
115(3) \\
74(2)\end{array}$ & $\begin{array}{l}\text { ptopril } \\
80(3) \\
109(2) \\
70(2)\end{array}$ & $\begin{array}{r}75(2) \\
108(2) \\
68(1)\end{array}$ & $\begin{array}{r}70(2) \\
121(3) \\
74(2)\end{array}$ & $\begin{array}{r}64(3) \\
127(4) \\
67(3)\end{array}$ \\
\hline $\begin{array}{l}\text { HR } \\
\text { SBP } \\
\text { DBP }\end{array}$ & $\begin{array}{r}83(3) \\
131(4) \\
83(2)\end{array}$ & $\begin{array}{r}85(2) \\
124(3) \\
79(2)\end{array}$ & $\begin{array}{l}\text { acebo } \\
82(2) \\
109(2) \\
73(1)\end{array}$ & $\begin{array}{r}76(2) \\
111(2) \\
72(1)\end{array}$ & $\begin{array}{r}72(2) \\
121(3) \\
78(2)\end{array}$ & $\begin{array}{r}67(3) \\
132(5) \\
83(3)\end{array}$ \\
\hline
\end{tabular}

HR, heart rate (beats/min); SBP, systolic blood pressure ( $\mathrm{mm} \mathrm{Hg}$; DBP, diastolic blood pressure ( $\mathrm{mm} \mathrm{Hg}$ ).

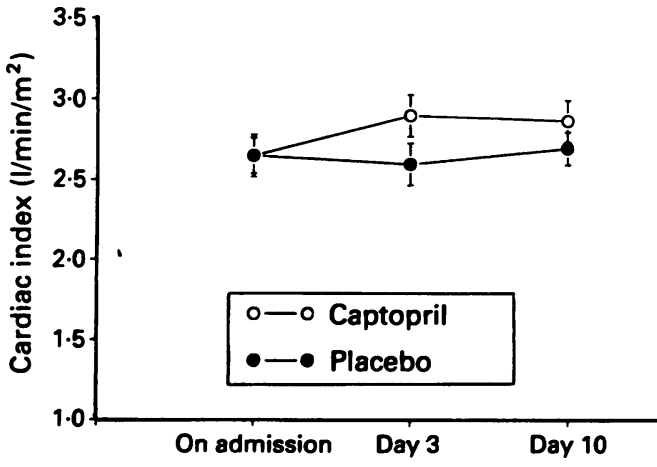

Figure 3 Mean (SEM) cardiac index by Doppler ultrasound.

irrespective of treatment. Plasma concentrations of catecholamines and arginine vasopressin were also unaffected by treatment.

\section{ECHOCARDIOGRAPHY}

At baseline there was a trend towards higher mean indices of left ventricular volume in the $\mathrm{G}$ placebo group consistent with the greater $\frac{}{5}$ incidence of previous infarcts (table 1). Table $\overrightarrow{\vec{z}}$ 6 shows the changes in echocardiographic indices from admission to one year in patients $\stackrel{3}{S}$ with analysable images. In both anterior and inferoposterior infarcts captopril limited the expansion of the endocardial segment containing the infarct that is the anterior segment in the anterior infarcts and the posterior segment in the inferoposterior infarcts (fig 4). This effect was less pronounced in the segments not containing an infarct. Ventricular dilatation was attenuated in the captopril group. At one year mean end systolic volume index was $47.0(2.8) \mathrm{ml} / \mathrm{m}^{2}$ in the captopril group and $59.9(3.4) \mathrm{ml} / \mathrm{m}^{2}$ in the placebo group ( $p=0.005$, fig 5). Corresponding figures for mean end diastolic volume index were $76.9(3.0) \mathrm{ml} / \mathrm{m}^{2}$ and $89.4(3.1) \mathrm{ml} / \mathrm{m}^{2}$ $(p=0.005$, fig 6$)$. Five of 30 patients in the captopril group developed an increase in left ventricular end systolic volume index $>2$ SDs of the measurement error compared with 15 of 31 in the placebo group $(p=0.001)$. The corresponding rates for end diastolic volume index were six of 30 in the captopril o group and 19 of 31 in the placebo group (p< $N$ $0.001)$. Excluding those patients with a previ- N ous infarct made no substantial difference to these results (table 6 ). The effects of captopril $\bullet$ on ventricular remodelling were, however, $\mathbb{D}$ less noticeable in patients with inferior infarcts. Withdrawal of treatment for one month had no effect on left ventricular volumes (figs 5 and 6).

EXERCISE VARIABLES

At the exercise test before discharge there was no difference in the occurrence of exercise induced ischaemia. Data on cardiopulmonary exercise testing at one year were available in 67 patients. There was no difference between the treatment groups in any variable (table 7). The exclusion of those patients with evidence of exercise induced ischaemia did not influ- 
Table 5 Serial hormone concentrations by treatment group

\begin{tabular}{|c|c|c|c|c|c|c|c|c|}
\hline & \multicolumn{4}{|l|}{ Captopril } & \multicolumn{4}{|l|}{ Placebo } \\
\hline & Baseline & Day 3 & Days $7-10$ & Two months & Baseline & Day 3 & Days $7-10$ & Two months \\
\hline $\operatorname{Renin}(\mu \mathrm{ul} / \mathrm{ml})$ & $\begin{array}{l}31 \\
(14-56)\end{array}$ & $\begin{array}{l}137^{\star} \\
(65-294)\end{array}$ & $\begin{array}{l}112^{\star \star} \\
(54-189)\end{array}$ & $\begin{array}{l}61^{\star} \\
(30-110)\end{array}$ & $\begin{array}{l}22 \\
(16-85)\end{array}$ & $\begin{array}{l}67 \\
(24-169)\end{array}$ & $\begin{array}{l}42 \\
(14-75)\end{array}$ & $\begin{array}{l}20 \cdot 5 \\
(12-48)\end{array}$ \\
\hline AII $(\mathrm{pg} / \mathrm{ml})$ & $\begin{array}{l}15 \cdot 6 \\
(4 \cdot 4-27 \cdot 5)\end{array}$ & $\begin{array}{l}10 \cdot 1^{\star} \\
(4 \cdot 8-19 \cdot 4)\end{array}$ & $\begin{array}{c}5 \cdot 2^{\star} \\
(2 \cdot 4-8 \cdot 1)\end{array}$ & $\begin{array}{l}3 \cdot 3^{\star \star} \\
(2 \cdot 0-5 \cdot 8)\end{array}$ & 12 (5.8-27.4) & $\begin{array}{l}16 \cdot 8 \\
(7 \cdot 3-46 \cdot 3)\end{array}$ & $\begin{array}{l}8 \cdot 1 \\
(5 \cdot 1-19 \cdot 0)\end{array}$ & $\begin{array}{l}6 \cdot 1 \\
(4 \cdot 0-14 \cdot 9)\end{array}$ \\
\hline $\mathrm{ANF}(\mathrm{pg} / \mathrm{ml})$ & $\begin{array}{l}72 \\
(49-100)\end{array}$ & $\begin{array}{l}(4 \cdot 8-19 \cdot 4) \\
99 \cdot 5 \\
(50-133)\end{array}$ & $\begin{array}{l}(2 \cdot 4-8 \cdot 1) \\
78 \\
(46-124)\end{array}$ & $\begin{array}{l}58 \\
(42-84)\end{array}$ & $\begin{array}{l}60 \\
(40-85)\end{array}$ & $\begin{array}{l}74 \\
(48-122)\end{array}$ & $\begin{array}{l}68 \cdot 5 \\
(35-100)\end{array}$ & $\begin{array}{l}(4 \cdot 0-14 \cdot 9) \\
58 \\
(35-94)\end{array}$ \\
\hline $\mathrm{ADR}(\mathrm{nmol} / \mathrm{l})$ & $\begin{array}{l}0.6 \\
(0.4-1 \cdot 2)\end{array}$ & $\begin{array}{c}0.3 \\
(0.1-0.6)\end{array}$ & $\begin{array}{c}0.2 \\
(0.1-0.2)\end{array}$ & $\begin{array}{l}0 \cdot 2 \\
(0 \cdot 1-0.3)\end{array}$ & $\begin{array}{l}0.6 \\
(0.4-0.3)\end{array}$ & $\begin{array}{l}0.2 \\
(0.1-0.3)\end{array}$ & $\begin{array}{l}0.2 \\
(0.1-0.2)\end{array}$ & $\begin{array}{l}0.2 \\
(0.1-0.2)\end{array}$ \\
\hline NADR (nmol/l) & $\begin{array}{l}4 \cdot 8 \\
3.6-6 \cdot 8)\end{array}$ & $\begin{array}{c}3 \cdot 4 \\
(2 \cdot 3-5 \cdot 0)\end{array}$ & $\begin{array}{l}2 \cdot 4 \\
(1 \cdot 8-3 \cdot 6)\end{array}$ & $\begin{array}{l}2 \cdot 6 \\
(2 \cdot 1-3 \cdot 6)\end{array}$ & $\begin{array}{l}4 \cdot 3 \\
(2 \cdot 7-6 \cdot 8)\end{array}$ & $\begin{array}{l}3.0 \\
(2.4-5.4)\end{array}$ & $\begin{array}{l}1.9 \\
(1.4-3.4)\end{array}$ & $\begin{array}{l}4 \cdot 1 \\
(1 \cdot 8-4 \cdot 8)\end{array}$ \\
\hline $\operatorname{AVP}(\mathrm{pg} / \mathrm{ml})$ & $\begin{array}{l}4 \cdot 63 \\
(2 \cdot 1-16 \cdot 0)\end{array}$ & $\begin{array}{c}0.99 \\
0.4-1.9)\end{array}$ & $\begin{array}{c}0.45 \\
(0.3-0.9)\end{array}$ & $\begin{array}{c}0.47 \\
(0 \cdot 2-1 \cdot 1)\end{array}$ & $\begin{array}{l}3 \cdot 22 \\
(0 \cdot 8-7 \cdot 2)\end{array}$ & $\begin{array}{l}1 \cdot 29 \\
(0 \cdot 6-3 \cdot 1)\end{array}$ & $\begin{array}{c}0.49 \\
(0.2-0.9)\end{array}$ & $\begin{array}{l}0.72 \\
(0 \cdot 2-1 \cdot 7)\end{array}$ \\
\hline
\end{tabular}

${ }^{\star} \mathrm{p}<0.05 ;{ }^{\star \star} \mathrm{p}<0.01$.

AII, angiotensin II; ANF, atrial natriuretic factor; ADR, adrenaline; NADR, noradrenaline; AVP, arginine vasopressin. Concentrations are median and interquartile range.

Table 6 Change in echocardiographic variables from admission to one year

\begin{tabular}{|c|c|c|c|c|}
\hline & Captopril & Placebo & (95\% CI of difference) & p Value \\
\hline \multicolumn{5}{|c|}{ Infarct segment (mm): } \\
\hline Ant MI & $\mathrm{n}=13$ & $\mathrm{n}=16$ & $(-21.750-3.5)$ & 0.000 \\
\hline Inf $M I$ & $\mathrm{n}=12$ & $\mathrm{n}=10$ & $(-21 \cdot 7$ to $-3 \cdot 3)$ & 0.009 \\
\hline & $4 \cdot 3(2 \cdot 4)$ & $13 \cdot 5(2 \cdot 8)$ & $(-17.7$ to -0.8$)$ & 0.033 \\
\hline \multicolumn{5}{|c|}{ Non-infarct segment $(\mathrm{mm})$ : } \\
\hline Ant $M I$ & $\begin{array}{l}\mathrm{n}=13 \\
3.8(2.2)\end{array}$ & $\begin{array}{l}\mathrm{n}=16 \\
7.0(3.5)\end{array}$ & $(-11.6$ to & 0.43 \\
\hline Inf MI & $\mathrm{n}=12$ & $\mathrm{n}=10$ & & \\
\hline & $6 \cdot 1(2 \cdot 2)$ & $14 \cdot 6(4 \cdot 4)$ & $(-19 \cdot 2$ to & $0 \cdot 11$ \\
\hline \multicolumn{5}{|c|}{ Left ventricular volumes $\left(\mathrm{ml} / \mathrm{m}^{2}\right)$ : } \\
\hline $\begin{array}{l}\text { All patients } \\
\text { LVEDVI }\end{array}$ & $\mathrm{n}=30$ & $\mathrm{n}=31$ & & \\
\hline LVEDVI & $8.4(1.9)$ & $19.0(2.6)$ & $(-17.0$ to $-4 \cdot 2)$ & 0.0016 \\
\hline LVESVI & $5.4(1.3)$ & $14 \cdot 7(2 \cdot 3)$ & $(-14.6$ to -3.9$)$ & 0.0011 \\
\hline SVI & $3.0(1 \cdot 2)$ & $4 \cdot 3(1 \cdot 5)$ & (- 2.5 to 5.2 ) & 0.48 \\
\hline $\mathrm{EF} \%$ & $-0.1(1.2)$ & $-\quad 1.9(1.7)$ & ( -2.5 to & 0.41 \\
\hline Ant $M I$ & $\mathrm{n}=17$ & $\mathrm{n}=20$ & & \\
\hline LVEDVI & $9 \cdot 2(2 \cdot 3)$ & $21 \cdot 3(3 \cdot 0)$ & $(-19.8$ to -4.3$)$ & 0.0015 \\
\hline LVESVI & $6.3(1.7)$ & $16.3(2.9)$ & $(-16.8$ to -3.2$)$ & 0.0054 \\
\hline SVI & $2.9(1.3)$ & $4.9(2.0)$ & (- 2.8 to 6.9 ) & 0.40 \\
\hline $\mathrm{EF} \%$ & $-0.9(1.4)$ & $-0.7(2.4)$ & (- 5.9 to & 0.93 \\
\hline Inf $M I$ & $\mathrm{n}=13$ & $\mathrm{n}=11$ & & \\
\hline LVEDVI & $7 \cdot 3(3 \cdot 1)$ & $14.8(4 \cdot 7)$ & $(-19.4$ to 4.4$)$ & $0 \cdot 20$ \\
\hline LVESVI & $4 \cdot 2(2 \cdot 1)$ & $11.6(3.9)$ & $(-16.9$ to & $0 \cdot 12$ \\
\hline SVI & $3 \cdot 1(2 \cdot 2)$ & $3 \cdot 2(2 \cdot 2)$ & ( -6.3 to & 0.97 \\
\hline $\mathrm{EF} \%$ & $1 \cdot 1(2 \cdot 2)$ & $-\quad 3.9(2.3)$ & (- 1.6 to 11.6$)$ & 0.13 \\
\hline First MI only & $\mathrm{n}=29$ & $\mathrm{n}=24$ & & \\
\hline LVEDVI & $8.3(1.9)$ & $20.9(3 \cdot 1)$ & $(-20 \cdot 1$ to $-5 \cdot 2)$ & 0.0015 \\
\hline LVESVI & $5 \cdot 3(1 \cdot 4)$ & $16 \cdot 7(2 \cdot 7)$ & $(-17.5$ to -5.3$)$ & 0.0005 \\
\hline SVI & $3.0(1 \cdot 2)$ & $4 \cdot 2(1 \cdot 6)$ & $(-2.8$ to 5.2$)$ & 0.55 \\
\hline $\mathrm{EF} \%$ & $0.1(1.3)$ & $-2.4(1.8)$ & $(-1.9$ to & $0 \cdot 26$ \\
\hline
\end{tabular}

Ant MI, anterior myocardial infarction; Inf $\mathrm{MI}$, inferoposterior myocardial infarction. Other abbreviations as for table 1. Captopril and placebo values are mean (SEM).

ence the results. Exercise capacity did not correlate with resting left ventricular volumes or ejection fraction. Withdrawal of treatment for one month had no significant effect on any exercise variable.

\section{Discussion}

In this study we have shown that captopril can be started safely within 24 hours of acute myocardial infarction in a population of patients at risk of progressive ventricular dilatation. To minimise the potential risks of hypotension we included only patients who were haemodynamically stable six hours after the start of chest pain. In the light of initial adverse reports about the combined use of captopril and streptokinase ${ }^{23}$ we elected to exclude streptokinase treated patients from the study. The study was started before the results of the Second International Study of Infarct Survival Trial were published, ${ }^{24}$ when the upper time limit for the use of streptokinase in our institutions was six hours, and before tissue plasminogen activator was readily available for routine use. Several small studies have shown that captopril is effective in treating left ventricular failure early after myocardial infarction ${ }^{25-27}$ but our trial is the first to examine targeted prophylactic captopril treatment in the period immediately after infarct. If acute captopril treatment is to gain acceptance as a measure to prevent late ventricular dilatation it must be free of significant side effects particularly during the acute dose period and the in hospital phase. With an incremental dose regimen we were able to introduce captopril without significant hypotension and with no evidence for clinically relevant aggravation of myocardial ischaemia either during the acute dose period or at the exercise test before discharge. Only two patients with a previous infarct were randomised to the captopril treatment and it is conceivable that hypotension might have been more apparent had there been more patients with a previous infarct in the capto-
Figure 4 Mean (SEM) change in length of segment containing infarct from admission to 12 months.

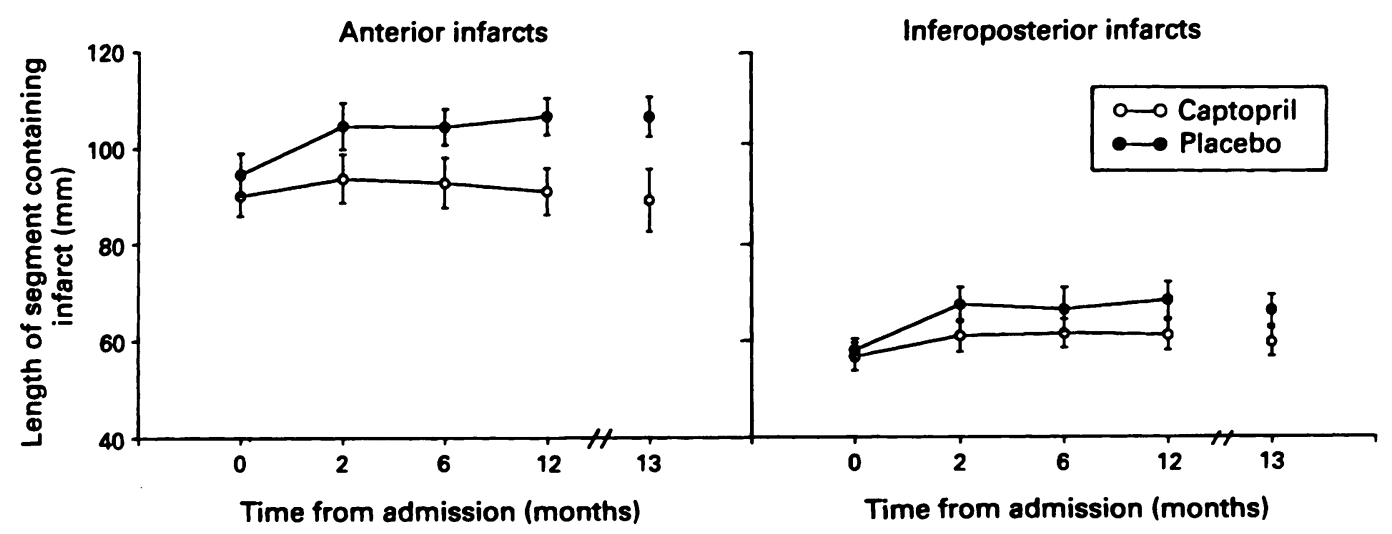


Figure 5 Mean (SEM) left ventricular end systolic and after one month after withdrawal from treatment. volume index from admission to 12 months

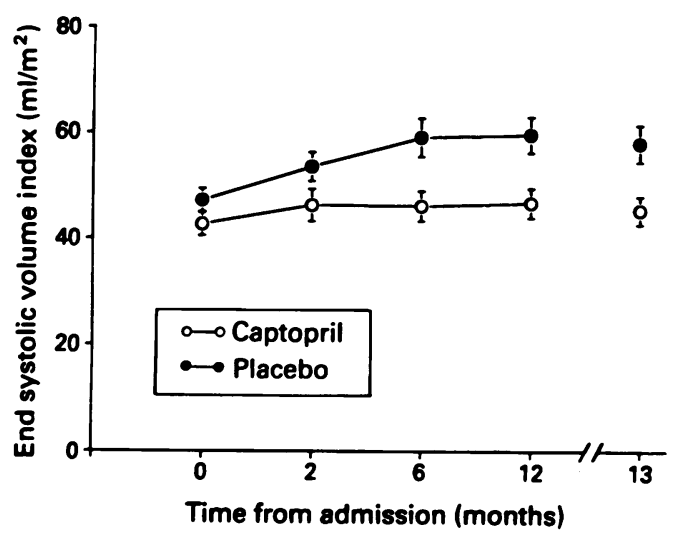

Figure 6 Mean (SEM) left ventricular end diastolic volume index from admission to 12 months and after one month after withdrawal from treatment.

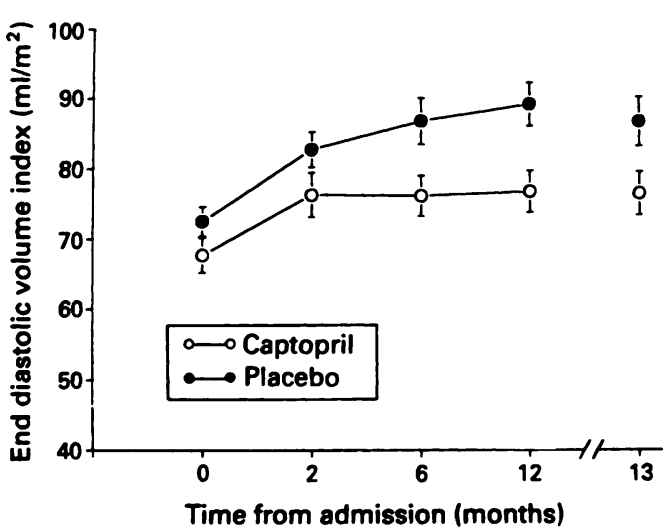

pril treated group. The immediate effects of captopril on cardiac filling pressures in this study are similar to those found in smaller studies of patients with postinfarction cardiac failure where similar dose schedules have been used. ${ }^{25} 26$ Despite acute vasodilatation captopril did not increase cardiac output either acutely or in the early convalescent phase.

The tendency to a greater degree of neuroendocrine activation in the captopril group at baseline is consistent with the trend to higher cardiac filling pressures and a higher peak creatine kinase in these patients. We have confirmed previous findings of stimulation of the renin angiotensin system three days after acute myocardial infarction even in the absence of diuretic treatment ${ }^{9}$. The mechanism for this effect remains uncertain but it

Table 7 Cardiopulmonary exercise testing at one year

\begin{tabular}{|c|c|c|}
\hline & $\begin{array}{l}\text { Captopril } \\
(n=35) \\
\text { Mean (SEM) }\end{array}$ & $\begin{array}{l}\text { Placebo } \\
(n=32) \\
\text { Mean (SEM) }\end{array}$ \\
\hline Exercise time (s) & $448(36)$ & $435(31)$ \\
\hline Peak HR & $138(4 \cdot 1)$ & $135(4 \cdot 3)$ \\
\hline Peak SBP $(\mathrm{mm} \mathrm{Hg})$ & $163(4 \cdot 2)$ & $167(4 \cdot 6)$ \\
\hline $\mathrm{Vo}_{2} \max \left(\mathrm{ml} / \mathrm{kg} / \mathrm{m}^{2}\right)$ & $23 \cdot 1(1 \cdot 1)$ & $22 \cdot 2(1 \cdot 0)$ \\
\hline $\mathrm{VCO}_{2} \max \left(\mathrm{ml} / \mathrm{kg} / \mathrm{m}^{2}\right)$ & $22.4(1.3)$ & $22 \cdot 7(1 \cdot 3)$ \\
\hline $\operatorname{VE}(1 / \mathrm{min})$ & $59 \cdot 1(3.5)$ & $62.6(3.5)$ \\
\hline & $1 \cdot 030(0.0$ & $1.026(0.022)$ \\
\hline $\begin{array}{l}\mathrm{ST}>-1 \mathrm{~mm} \\
\text { Time to } \mathrm{ST}-1 \mathrm{~m}\end{array}$ & $\begin{array}{l}11 \\
330(46)\end{array}$ & $327(58)$ \\
\hline
\end{tabular}

$\mathrm{VO}_{2}$, oxygen uptake; $\mathrm{VCO}_{2}$, carbon dioxide output; VE, ventilation; RER, respiratory exchange ratio; $S T>-1$, number of patients developing $>1 \mathrm{~mm}$ of ST elevation. Other abbreviations as for table 4 . may be related to increased sympathetic outflow to the renal nerves and hence increased renin secretion. ${ }^{28}$ Captopril prevented the rise in concentrations of angiotensin II at day three and, compared with placebo, concentrations remained depressed at two months. As well as its potent vasoconstrictor and antinatriuretic actions, angiotensin II is cardiotoxic ${ }^{2930}$ and raised concentrations in the immediate aftermath of myocardial infarction may be particularly deleterious. The prompt use of an angiotensin converting enzyme inhibitor should minimise these harmful effects.

We have confirmed the occurrence of a peak in plasma atrial natriuretic factor two to के four days after infarction. ${ }^{30}{ }^{31}$ Previous studies $\vec{\circ}$ have found concentrations of plasma atrial natriuretic factor to be raised for up to 15 days, ${ }^{32}$ but a persistent increased concentration over two months after acute myocardial infarction has not previously been reported and presumably reflects persistent left ven- i tricular dysfunction (left ventricular ejection $\vec{G}$ fractions at two months were $40.4 \%(2 \cdot 0 \%)$ ㅇ in the captopril group and $36 \%(1.2 \%)$ in the placebo group). Chronic captopril treatment 3 after acute myocardial infarction both lowers cardiac filling pressures and improves left ventricular function ${ }^{56}$ and would thus be expected to lower plasma concentrations of atrial natriuretic factor. Previous studies have been contradictory. McAlpine et al found that acute doses of captopril in patients with acute left ventricular failure had no consistent effects on atrial natriuretic factor despite a significant fall in both right atrial and pul- $\overrightarrow{\overrightarrow{0}}$ monary capillary wedge pressures ${ }^{33}$. In patients with chronic stable heart failure Rouleau et al noted an acute fall in plasma concentrations after the initial dose but after one month of treatment concentrations were similar to those at baseline. ${ }^{34}$ These findings suggest that captopril might modify the release of atrial natriuretic factor such that secretion is increased for a given degree of atrial distension and is less sensitive to a fall in atrial pressure. This hypothesis, however, is not supported by the results of other studies. Swedberg et al found a $20 \%$ fall in con- N centrations of atrial natriuretic factor after six $N$ weeks of enalapril treatment in patients with severe chronic heart failure. ${ }^{35}$ In acute dose studies in salt replete normal volunteers captopril has either no effect, ${ }^{36}$ or increases circulating concentrations of atrial natriuretic factor. ${ }^{37}$ In salt depleted patients with an activated renin angiotensin system enalapril reduces concentrations acutely. ${ }^{38}$ In the light of these conflicting results it is likely that the interaction between atrial natriuretic factor 2 and inhibition of angiotensin converting enzyme is complex. It is possible that in patients with a considerably activated renin angiotensin system the vasodilator action of $\underset{P}{\rightleftharpoons}$ converting enzyme inhibition is predominant, resulting in a fall in atrial distension and thus a fall in circulating atrial natriuretic factor. In subjects with a lesser degree of activation of the renin angiotensin system the haemody- 
namic effects of converting enzyme inhibition are less noticeable and modification of secretion could predominate. If this is the case then this may be an advantage for converting enzyme inhibitors over other vasodilators.

Concentrations of arginine vasopressin in this study are similar to those described previously. ${ }^{9}$ In patients with stable heart failure long-term captopril treatment leads to a reduction in arginine vasopressin ${ }^{39}$ but there is no effect with short term treatment either in stable heart failure ${ }^{40}$ or in acute left ventricular failure where concentrations are noticeably increased. ${ }^{33}$ In acute and chronic heart failure the effects of converting enzyme inhibition on catecholamines have been variable with either no effect ${ }^{3340}$ or a decrease in noradrenaline. ${ }^{27}{ }^{41}$ At the time of entry to the present study median concentrations of both adrenaline and noradrenaline were in the upper reaches of the normal range and it would have been surprising had any effect of captopril been seen. The initial fall, however, in arterial pressure in the captopril group in the absence of a compensatory tachycardia provides indirect evidence of a sympatholytic effect.

We have shown that oral captopril started within 24 hours of symptoms greatly reduces left ventricular remodelling over the first year after acute myocardial infarction. Left ventricular dilatation begins within hours of transmural myocardial necrosis and is particularly rapid over the first $10-14$ days. ${ }^{578}$ At one week after infarction left ventricular end systolic volume index is already $85 \%$ above normal and left ventricular end diastolic volume index $35 \%$ above normal. ${ }^{5}$ Sharpe et al found that captopril started at a mean of nine days after infarction and continued for a year caused a significant reduction in left ventricular end systolic volume index and an increase in stroke volume index from baseline. ${ }^{5}$ In a second study the same authors randomised patients to captopril or placebo at 24-48 hours after admission and followed them up for three months. ${ }^{42}$ Early captopril treatment prevented much of the dilatation present at baseline in their original study. It is not possible to draw a direct comparison with our study as we included patients with more severe degrees of left ventricular impairment. We started captopril at a mean of 15 hours from symptoms in a population of patients selected on simple clinical grounds alone as being at risk of progressive left ventricular dilatation. Preliminary results from other studies suggest that it is safe to start angiotensin converting enzyme inhibition at an even earlier stage after infarction, though the benefits of this approach are not yet clear.

Thirteen of the 15 patients with a previous infarct were randomised to placebo. To account for this inequality we reanalysed our data to include only those patients with a first myocardial infarction and this made no significant difference to the overall findings. Second infarcts cause less remodelling than first infarcts ${ }^{43}$ and the uneven distribution would if anything have tended to reduce the extent of ventricular enlargement from baseline in the placebo group. We deliberately selected patients at risk of ventricular dilatation. About $40 \%$ of the total increase in left ventricular volumes in our placebo patients occurred in the first 10 days after infarction but chamber dilatation continued over the course of the study. Similar persistence of ventricular dilatation has been found in other studies. ${ }^{144}$ The optimal duration of captopril treatment remains to be defined but our results suggest that it should be continued for at least a year and possibly indefinitely. The lack of a change in ventricular volumes in the captopril group after the month of treatment withdrawal confirms that the reduction in ventricular dilatation is structural and not due simply to a rapidly reversible haemodynamic effect. It does not allow us to determine the mechanism underlying the effect of captopril.

None of the patients in our study received thrombolytic treatment. Thrombolysis and a patent infarct related artery reduce the extent of ventricular remodelling ${ }^{44}{ }^{45}$ but captopril is none the less effective in attenuating ventricular dilatation in patients treated with streptokinase $^{46}$ and probably in those treated with tissue plasminogen activator. ${ }^{47} \mathrm{~A}$ significant proportion of patients with acute myocardial infarction have either contraindications to the use of thrombolytics, present too late for effective thrombolysis, or fail to reperfuse. These are the patients who probably have most to gain from treatment with captopril.

We were unable to show any benefit of captopril treatment on aerobic exercise capacity and there was no correlation between exercise capacity and resting left ventricular function. Captopril improves exercise capacity in patients with congestive cardiac failure ${ }^{48}$ but few of our patients fell into this category. In both treatment groups maximal oxygen uptake was in the low normal range. ${ }^{49} \mathrm{By}$ contrast Pfeffer et al found exercise time to be significantly prolonged in captopril treated patients but included only those who did not develop exercise induced ischaemia. ${ }^{6}$ To allow a better comparison we reanalysed our data to exclude patients developing exercise induced ischaemia but this had no material effect on the outcome.

Our study indicates that captopril treatment within 24 hours of acute myocardial infarction is a practical strategy to limit progressive left ventricular dilatation in high risk patients identified on simple clinical grounds alone. Withdrawal of captopril did not lead to a rapid reversal of these changes implying that they have a structural basis. The eventual place of angiotensin converting enzyme inhibition in the management of myocardial infarction will be dependent on evidence that their beneficial effects on remodelling are converted long-term into a reduction in mortality and improved functional state. Although the Consensus 2 Study failed to show a reduction in mortality with enalapril ${ }^{50}$ the initial results of the SAVE (Survival and Ventricular Enlargement Study) show that captopril reduced both cardiovascular mortal- 
ity and progression to cardiac failure when started between three and 16 days after infarction in patients with an ejection fraction below $40 \% .^{51}$

We are grateful to Ms Esther Henderson for invaluable help with this study.

1 Jeremy RW, Allman KC, Bautovitch G, Harris PJ. Patterns of left ventricular dilatation during the six Patterns of left ventricular dilatation during the six $1989 ; 13: 304-10$

2 Warren SE, Royal HD, Markis JE, Grossman W, McKay RG. Time course of left ventricular dilatation after acute myocardial infarction: influence of the infarct related artery and success of coronary thrombolysis. $f \mathrm{Am} \mathrm{Coll}$ Cardiol 1988; 11:12-9.

3 White HD, Norris RM, Brown MA, Brandt PWT, Whitlock RML, Wild CJ. Left ventricular end systolic volume as the major determinant of survival after recovery from myocardial infarction. Circulation 1987; 76:44-51.

4 Kannel WB, Sorlie P, McNamara PM. Prognosis after initial myocardial infarction: the Framingham Study. $A m$ tial myocardial infarction:

5 Sharpe N, Murphy J, Smith H, Hannan S. Treatment of patients with symptomless left ventricular dysfunction following acute myocardial infarction. Lancet 1988, i: $255-9$

6 Pfeffer MA, Lamas GA, Vaughan DE, Parisi AF, Braunwald E. Effect of captopril on progressive ventric-
ular dilatation after anterior myocardial infarction. $N$ Engl ₹ Med 1988; 319:80-6.

7 Hochman JS, Bulkley BH. Expansion of acute myocardial infarction: an experimental study. Circulation 1982; 65:1446-50.

8 Picard MH, Wilkins GT, Ray PA, Weyman AE. Natural history of left ventricular size and function after acute history of left ventricular size and function after

9 McAlpine HM, Morton JJ, Leckie B, Rumley A, Gillen G, Dargie HJ. Neuroendocrine activation after acute myocardial infarction. Br Heart $\mathcal{f} 1988 ; 60: 117-24$

10 Oldroyd KG, Pye M, Ray SG, et al. Effects of early captopril administration on infarct expansion, left ventricular remodelling and exercise capacity after acute myocardial infarction. Am $\mathcal{F}$ Cardiol 1991; 68:304-10.

11 Norris RM, Brandt PWT, Caughey DE, Lee AJ, Scott PJ. A new coronary prognostic index. Lancet 1969; i: $117-24$.

12 Pearlman AS. Evaluation of cardiac function by Doppler echocardiographic techniques. In: Marcus ML, Schelbert HR, Skorton DJ, Wolf GL, eds. Cardiac Schelbert HR, Skorton DJ, Wolf GL, eds. Cardia

13 Miller JA, Leckie B, Morton JJ, Jordan J, Tree M. A microassay for active and total renin concentration based on antibody trapping. Clinica Chemica Acta 1980; 101:5-15.

14 Morton JJ, Webb DJ. Measurement of plasma angiotensin II. Clin Sci 1985; 68:483.

15 Ball SG, Tree M, Morton JJ, Inglis GC, Fraser R. Circulating dopamine: its effect on the plasma concentrations of catecholamines, renin, angiotensin, aldos-
terone and vasopressin in the conscious dog. Clin Sci $1981 ; 61: 417-22$.

16 Morton JJ, Connell JMC, Hughes MJ, Inglis GC, Wallace $\mathrm{ECH}$. The role of plasma osmolality, angiotensin II and dopamine in vasopressin release in man. Clinical Endocrinology 1985; 23:129-38.

17 Richards AM, Tonolo G, McIntyre G, Leckie B, Robertson JIS. Radioimmunoassay for plasma alpha human atrial natriuretic peptide: A comparison of direct and re-extracted methods. $f$ Hypertens 1987; 5:227-36.

18 Eaton LW, Weiss JL, Bulkley BH, Garrison JB, Weisfeldt ML. Regional cardiac dilatation after acute myocardial infarction. N Engl ₹ Med 1979; 300:57-62.

19 Tortoledo FA, Quinones MA, Fernandez GC, Waggoner $A D$, Winters WL. Quantification of left ventricular volumes by two-dimensional echocardiography; a simplified and accurate approach. Circulation 1983; 67:579-84

20 Starling MR, Crawford MH, Sorensen SG, Levi B, Richards KI, O'Rourke RA. Comparative accuracy of apical biplane cross-sectional echocardiography and apical biplane cross-sectional echocardiography and gated equilibrium radionuclide angiography for estimating left $63.1075-83$.

21 Bland JM, Altman DG. Statistical methods for assessing agreement between two methods of clinical measurement. Lancet $1986 ; \mathbf{i}: 307-10$

22 Snedecor GW, Cochran WG. Statistical methods. 6th edition. Ames, Iowa: Iowa University Press, 1962;115.

23 Kingma JH, van Gilst WH, de Graeff P, Louwerenborg HW, Six AJ, Wesseling H. Captopril during thrombolysis in myocardial infarction: feasibility, tolerance and beneficial neurohumoral effects. In: Sever P, McGregor $\mathrm{GA}$, eds. Current advances in $A C E$ inhibition. EA, eds. Current advances in $A C E$.

24 Second International Study of Infarct Survival Collaborative Group. Randomized trial of intravenous Collaborative Group. Randomized trial of intravenous 17,178 cases of suspected acute myocardial infarction;
ISIS 2. Lancet 1988; 2:349-60.

25 McAlpine HM, Morton JJ, Leckie B, et al. Haemodynamic effects of captopril in acute left ventricular failure complicating acute myocardial infarction. $f$ Cardiovasc Pharmacol 1987; 9(suppl 2):525-30.

26 Mattioli G, Ricci S, Rigo R, Fusaro MT, Cappello C. Effects of captopril in heart failure complicating acute myocardial infarction and persistence of acute haemodynamic effects in chronic heart failure after three years of treatment. Postgrad Med F 1986; 62(suppl 1):164-6.

27 Wenting GJ, Man in't Veld, Woittiez AJ, Boomsma F, Laird-Meeter K, Simoons ML, et al. Effects of captopril in acute and

28 Stella $\mathrm{A}$, Zanchetti $\mathrm{A}$. The renin angiotensin system: physiological regulation of renin release. In: Zanchetti A Tarazi RC, eds. Handbook of hypertension, Vol 8: pathophysiology of hypertension regulatory mechanisms. physiology of hypertension

29 Tan LB, Jalil JE, Janicki JS, Weber KT, Clark WA Cardiotoxic effects of angiotensin II [abstract]. $\mathcal{f} A m$ Coll Cardiol 1989; 13:2A.

$30 \mathrm{H}$ Gavras, Kremer D, Brown JJ, Gray B, Lever AF, McAdam RF, et al. Angiotensin and norepinephrine induced myocardial lesions: experimental and clinical studies in rabbits and man. Am Heart $\mathcal{f} 1975$; 89:321-32.

31 Ngo L, Vesely DL, Bissett JK, et al. Acute and sustained release of atrial natriuretic factor with acute myocardial infarction. Am Heart f 1989; 118:893-900.

32 Fontana F, Bernardi P, Spagnolo N, Capelli M. Plasma atrial natriuretic factor in patients with acute myocardial atrial natriuretic factor in patients with acut
infarction. Eur Heart $₹$ 1990; 11:779-87.

33 McAlpine H, Polonia J, Morton JJ, Rumley A, Dargie H. Neuroendocrine responses in acute heart failure after myocardial infarction [abstract]. Br Heart $\mathcal{f} 1989 ; 61: 80$

34 Rouleau JL, Bichet D, Kortas C. Atrial natriuretic peptid in congestive heart failure: postural changes and reset
with chronic captopril therapy. Am Heart $\mathcal{f} 1988$; 115:1060-7.

35 Swedberg K, Eneroth P, Kjekshus J, Wilhemsen L Hormones regulating cardiovascular function in patients with severe congestive heart failure and their relation to mortality. Circulation 1990; 82:1730-6.

36 Richards AM, Rao G, Espiner EA, Yandle T. Interaction of angiotensin converting enzyme inhibition and atrial natriuretic factor. Hypertension 1989; 13:193-9.

37 Wilkins MR, Lewis HM, West MJ, Kendall MJ, Lote CJ. Captopril reduces the renal response to intravenous atrial natriuretic peptide in normotensives. F Hum Hyperten 1987; 1:47-51.

38 Mann FE, Lang RE, Leidig M, Ritz E. Effect of angiotensin I converting enzyme inhibition on circulating atrial natriuretic peptide in humans. Klin Wochenschr 1986; 64(suppl 4):13-5.

39 Riegger GA, Kochsiek K. Vasopressin, renin and norepinephrine levels before and after captopril administration in patients with congestive heart failure due to idiopathic dilated cardiomyopathy. Am $¥$ Cardiol 1986; ic dilated

40 Levine TB, Olivari MT, Gardberg V, Sharkey SW, Cohn JN. Haemodynamic and clinical response to enalapril, a long acting converting enzyme inhibitor, in patients with congestive heart failure. Circulation 1984; 69:548-53.

41 Cleland J, Semple P, Hodsman P, Ball S, Ford I, Dargie HJ. Angiotensin II levels, haemodynamics, and sympathoadrenal function after low dose captopril in heart failure. $\mathrm{Am}$ f Med 1984; 77:880-6.

42 Sharpe N, Smith $\mathrm{H}$, Murphy J, Greaves S, Hart $\mathrm{H}$, Gamble G. Early prevention of left ventricular dysfunction following myocardial infarction. Lancet 1991; i:872-4.

43 Hutchins GM, Bulkley BH. Infarct expansion versus extension: Two different complications of acute $N$ myordial infarction. Am $¥$ Cardiol 1978; 41:1127-32.

44 Gadsboll N, Hoilund-Carlsen P-F, Badsberg JH, Stage P, Marving J, Lonborg-Jensen $H$. Late ventricular dilatation in survivors of acute myocardial infarction. $A m \mathcal{F}$ Cardiol 1989; 64:961-6.

45 Jeremy RW, Hackworthy RA, Bautovitch G, Hutton BF, Harris PJ. Infarct artery perfusion and changes in left $c$ ventricular volume in the month after acute myocardial infarction. $\mathcal{7}$ Am Coll Cardiol 1987; 9:989-95.

46 Bonaduce D, Petretta $M$, Villari $B$, et al. Effects of late : administration of tissue-type plasminogen activator on left ventricular remodelling and function after myocardial infarction. $\mathcal{F}$ Am Coll Cardiol 1990; 16:1561-8.

47 Nabel EG, Topol EJ, Galeana A, et al. A randomised placebo controlled trial of combined early intravenous $\mathbb{D}$ captopril and recombinant tissue type plasminogen activator therapy in acute myocardial infarction. $\mathcal{f} \mathrm{Am}$ Coll Cardiol 1991; 17:467-73.

48 Captopril Multicentre Research Group. A placebo controlled trial of captopril in refractory chronic congestive cardiac failure. $7 \mathrm{Am}$ Coll Cardiol 1983; 2:755-63.

49 Franciosa JA. Exercise testing in chronic congestive car- $\bar{Q}$ diac failure. Am $\mathcal{f}$ Cardiol $1984 ; 53: 1447-550$.

50 Swedberg K. Lack of beneficial effects on mortality by early intervention with enalapril in acute myocardial infarction [abstract]. Circulation 1991; 84:II-366.

51 Pfeffer MA, Braunwald E, Moye LA, et al. The effect of captopril on mortality and morbidity in patients with left ventricular dysfunction after myocardial infarctionresults of the survival and ventricular enlargement trial. N Engl F Med 1992;327:669-78. 